\title{
Selective potentiation of alpha 1 glycine receptors by ginkgolic acid
}

\author{
Galyna Maleeva ${ }^{1,2,3+}$, Svetlana Buldakova ${ }^{1,2+}$ and Piotr Bregestovski ${ }^{1,2 *}$ \\ ${ }^{1}$ Aix Marseille Université, INS UMR_S 1106, Marseille, France, ${ }^{2}$ INSERM, UMR_S 1106, Marseille, France, ${ }^{3}$ Department of \\ Cytology, Bogomoletz Institute of Physiology, Kyiv, Ukraine
}

\section{OPEN ACCESS}

Edited by:

Hans-Georg Breitinger,

The German University in Cairo, Egypt

Reviewed by:

Carmen Villmann

Julius-Maximilians-University

Würzburg, Germany

Ralf Enz,

Friedrich-Alexander-Universität Erlangen-Nürnberg, Germany

*Correspondence:

Piotr Bregestovski

piotr.bregestovski@univ-amu.fr;

pbreges@gmail.com

tThese authors have contributed equally to this work.

Received: 19 July 2015 Accepted: 16 October 2015 Published: 29 October 2015

Citation:

Maleeva G, Buldakova S and Bregestovski $P$ (2015) Selective potentiation of alpha 1 glycine receptors by ginkgolic acid.

Front. Mol. Neurosci. 8:64. doi: 10.3389/fnmol.2015.00064
Glycine receptors (GlyRs) belong to the superfamily of pentameric cys-loop receptoroperated channels and are involved in numerous physiological functions, including movement, vision, and pain. In search for compounds performing subunit-specific modulation of GlyRs we studied action of ginkgolic acid, an abundant Ginkgo biloba product. Using patch-clamp recordings, we analyzed the effects of ginkgolic acid in concentrations from $30 \mathrm{nM}$ to $25 \mu \mathrm{M}$ on $\alpha 1-\alpha 3$ and $\alpha 1 / \beta, \alpha 2 / \beta$ configurations of GlyR and on $\mathrm{GABA}_{A} \mathrm{Rs}$ expressed in cultured $\mathrm{CHO}-\mathrm{K} 1$ cells and mouse neuroblastoma (N2a) cells. Ginkgolic acid caused an increase in the amplitude of currents mediated by homomeric $\alpha 1$ and heteromeric $\alpha 1 / \beta$ GlyRs and provoked a left-shift of the concentration-dependent curves for glycine. Even at high concentrations (10-25 $\mu \mathrm{M})$ ginkgolic acid was not able to augment ionic currents mediated by $\alpha 2, \alpha 2 / \beta$, and $\alpha 3$ GlyRs, or by $G A B A_{A} R$ consisting of $\alpha 1 / \beta 2 / \gamma 2$ subunits. Mutation of three residues (T59A/A261G/A303S) in the $\alpha 2$ GlyR subunit to the corresponding ones from the $\alpha 1$ converted the action of ginkgolic acid to potentiation with a distinct decrease in $\mathrm{EC}_{50}$ for glycine, suggesting an important role for these residues in modulation by ginkgolic acid. Our results suggest that ginkgolic acid is a novel selective enhancer of $\alpha 1$ GlyRs.

Keywords: ligand-gated channels, glycine receptor, ion currents, whole-cell recording, patch clamp, $\mathrm{CHO}$ cells

\section{INTRODUCTION}

Anion-selective GlyR channels provide the inhibitory drive in the vertebrate spinal cord, brainstem, retina and some other parts of central and peripheral nervous system (Malosio et al., 1991; Lynch, 2004; Betz and Laube, 2006). Together with cation-selective nicotinic acetylcholine receptors and serotonin type 3 receptors, as well as with anion-selective $G_{A B A}$ and $G A B A_{C}$ receptors, they belong to the superfamily of pentameric cys-loop receptor-operated channels (Smart and Paoletti, 2012; Lynagh and Pless, 2014).

The family of GlyRs is relatively small. Molecular cloning has enabled identification of four alpha subunits $(\alpha 1-\alpha 4)$ and one beta $(\beta)$ subunit with several splice variants (Laube et al., 2002; Lynch, 2004; Oertel et al., 2007; Dutertre et al., 2012). Functional GlyRs can be either homomeric, formed from five $\alpha$ subunits, or heteromeric, formed from $\alpha$ and $\beta$ subunits with still not definitively determined stoichiometry, suggesting either $3 \alpha / 2 \beta$ (Langosch et al., 1988, 1990; Burzomato et al., 2003; Durisic et al., 2012) or $2 \alpha / 3 \beta$ (Grudzinska et al., 2005; Yang et al., 2012)

Abbreviations: CB receptor, cannabinoid receptor; cDNA, complementary deoxyribonucleic acid; $\mathrm{CHO}$ cells, Chinese hamster ovary cells; DMSO, dimethyl sulfoxide; $\mathrm{EC}_{50}$, half-maximal concentration; GABA, $\gamma$-aminobutyric acid; $\mathrm{GABA}_{\mathrm{A}} \mathrm{R}$, $\gamma$-aminobutyric acid receptor, subtype A; GlyR, glycine receptor; $\mathrm{I}_{\text {gly }}$, glycine-induced current; THC, $\Delta^{9}$-tetrahydrocannabiol; TM, transmembrane domain; WT, wild type. 
composition. Alpha subunits are highly homologous, with primary structures displaying $80-90 \%$ amino acid sequence identity (Lynch, 2004); however, they differ in their kinetic properties (Takahashi et al., 1992; Singer and Berger, 1999), temporal and regional expression (Malosio et al., 1991; Betz and Laube, 2006; Heinze et al., 2007; Dlugaiczyk et al., 2008; Aroeira et al., 2011) and physiological functions (Harvey et al., 2004; Villmann et al., 2009; Dutertre et al., 2012).

Due to their diverse distribution and functions, GlyRs are potential pharmacological targets for muscle relaxant, analgesic and anti-inflammatory drugs (Webb and Lynch, 2007; Zeilhofer et al., 2012), however, only a few compounds with preferable subunit specificity are known (Yang et al., 2008; Lynch, 2009; Balansa et al., 2013).

Several studies have demonstrated that ginkgolides, extracted from the leaves of the Ginkgo biloba tree, are specific and potent blockers of GlyR channels (Kondratskaya et al., 2002, 2004; Hawthorne et al., 2006). Ginkgo biloba extract contains three groups of active substances: (i) flavonoid glycosides including quercetin and rutin; (ii) terpene trilactones (ginkgolide A, B, C, J, and bilobalide) (Ude et al., 2013); and (iii) ginkgolic acids, which are predominantly contained in the nutshells and leaves (Jaggy and Koch, 1997; Fuzzati et al., 2003).

It has been shown that ginkgolide B displays subtypeselectivity, albeit weak, with about 5- and 3-fold preferences for $\alpha 1$ vs. $\alpha 2$ and $\alpha 3$ GlyR subunits, respectively (Kondratskaya et al., 2005). Moreover, the inhibitory ability of ginkgolide B was 5- to 100-fold higher on heteromeric than on homomeric GlyRs, i.e., incorporation of the $\beta$ subunit substantially increased the antagonism of this compound (Kondratskaya et al., 2005). Similarly to that, the other terpen trialactones from Ginkgo biloba extract (ginkgolide A, C, and bilobalide) block GlyR channels though with weak subunit discrimination (Hawthorne et al., 2006; Lynch, 2009). Quercetin, belonging to the flavanoid group, also inhibits $\alpha 1$ GlyR activity (Lee et al., 2008) in a non-competitive manner, with an $\mathrm{IC}_{50}$ of about $45 \mu \mathrm{M}$ (Raafat et al., 2010). This compound also inhibits $\mathrm{GABA}_{\mathrm{A}}$ and $\mathrm{GABA}_{\mathrm{C}}$ receptors (Kim et al., 2015), causing seizures in animal models (Nassiri-Asl et al., 2014).

The functional properties of ginkgolic acid have attracted much less attention. Ginkgo biloba extract, used in medicine, is cleared of ginkgolic acid because of the latter's possible side effects (Ahlemeyer et al., 2001; Hecker et al., 2002). However, it has been shown that as long as the carboxylic acid group is intact, either in free or in conjugated forms, no allergic manifestations are detected (Satyan et al., 1998). Moreover, it has been suggested that intact carboxylic acid groups are the bioactive components of the lipophilic extract of Ginkgo biloba leaves with antidepressant and antistress activities (Kalkunte et al., 2007). As, in contrast to ginkgolides, the effects of ginkgolic acid on the function of GlyRs and other receptor-operated channels have not been studied, we analyzed here the action of a specific compounds, a simple unsaturated ( $R=\mathrm{C} 15: 1$ ) ginkgolic acid (Figure 1A), on GlyRs and GABARs.

Using patch-clamp technique, we studied the effects of ginkgolic acid on ionic currents induced by activation of receptor-operated channels expressed in $\mathrm{CHO}$ and neuroblastoma cells. We have shown that ginkgolic acid causes specific potentiation of currents mediated by $\alpha 1$ GlyR subunits without strong modulation of $\alpha 2, \alpha 3$ GlyR, or $\mathrm{GABA}_{\mathrm{A}}$ receptors. Moreover, three aminoacids, mutation of which transformed the inhibitory effect of ginkgolic acid into potentiation, were identified in $\alpha 2$ GlyRs.

\section{MATERIALS AND METHODS}

\section{Primary Culture and Transfection}

The experiments were carried out on cultured Chinese hamster ovary (CHO-K1) cells obtained from the American Type Tissue Culture Collection (ATCC, Molsheim, France) and on mouse neuroblastoma cells ( $\mathrm{N} 2 \mathrm{a}$ ) cells that were maintained in culture conditions as previously described (Waseem et al., 2010; Mukhtarov et al., 2013).

For electrophysiological analysis cells were transfected with cDNAs of different receptor-operated channels. One day before the transfection, cells were plated on the coverslips $(12-14 \mathrm{~mm}$ in diameter), which were placed inside $35-\mathrm{mm}$ cell culture dishes with $2 \mathrm{ml}$ of medium. CHO-K1 cells were transfected with the following cDNAs encoding GlyR subunits: human $\alpha 1(1 \mu \mathrm{g} / 1 \mu \mathrm{l})$, $\alpha 2(2 \mu \mathrm{g} / 1 \mu \mathrm{l}), \alpha 3$-long $(2 \mu \mathrm{g} / 1 \mu \mathrm{l})$, and $\beta$ (in combination with $\alpha 1$ or $\alpha 2$ subunits with the ratio of cDNAs concentrations $1 \alpha: 5 \beta$ ); or with a mixture of $c D N A s$ encoding $\mathrm{GABA}_{\mathrm{A}}$ receptors: $\alpha 1$-GFP $(1 \mu \mathrm{g} / \mu \mathrm{l}), \beta 2(1 \mu \mathrm{g} / \mu \mathrm{l}), \gamma 2(1 \mu \mathrm{g} / \mu \mathrm{l})$ using the Lipofectamine 2000 transfection protocol (Life Technology, USA). To facilitate identification of expressing cells, in the case of GlyR, green fluorescent protein (GFP, $0.5 \mu \mathrm{g} / \mu \mathrm{l}$ ) was added to the transfection medium. Visualization of $\mathrm{GABA}_{\mathrm{A}} \mathrm{R}$ expression was achieved by using the $\alpha 1$-GFP construct (Bueno et al., 1998). Three hours after the initial exposure of the cells to the cDNAs, a fresh solution replaced the old one. To prevent spontaneous activation of GlyRs by the small amount of glycine present in culture medium, strychnine $(1 \mu \mathrm{M})$ was added to cultures expressing all types of GlyR subunits. Electrophysiological recordings were performed on fluorescent cells $24-72 \mathrm{~h}$ after transfection.

\section{Electrophysiological Recordings}

Whole-cell recordings were performed at room temperature (20$25^{\circ} \mathrm{C}$ ) using an EPC-9 amplifier (HEKA Elektronik, Germany). Cells were continuously superfused with external solution containing (mM): $\mathrm{NaCl} 140, \mathrm{CaCl}_{2} 2, \mathrm{KCl} 2.8, \mathrm{MgCl}_{2} 4$, HEPES 20 , glucose 10; pH 7.4; 320-330 mOsm. Two intracellular solutions were used for filling recording patch pipettes. First, mainly used, 'CsCl solution' contained (mM): $\mathrm{CsCl} 140, \mathrm{CaCl}_{2} 6$, $\mathrm{MgCl}_{2}$ 2, MgATP 2, NaGTP 0.4, HEPES/CsOH 10, BAPTA/KOH 20; $\mathrm{pH} 7.3 ; 290$ mOsm. In the experiments performed with $\mathrm{CsCl}$ intracellular solution, ionic currents were recorded at holding potential $\left(\mathrm{V}_{\mathrm{h}}\right)-30 \mathrm{mV}$. In some experiments, 'Kgluconate solution' was used, in which $\mathrm{CsCl} 140 \mathrm{mM}$ was replaced by $\mathrm{KCl} 20 \mathrm{mM}+$ Kgluconate $120 \mathrm{mM}$. Recordings with this solutions were performed at $\mathrm{V}_{\mathrm{h}}=0 \mathrm{mV}$. Pipettes were pulled from borosilicate glass capillaries (Harvard Apparatus Ltd, USA) and had resistances of 5-10 MOhms. For rapid replacement of solutions, the fast application system was used in this study. Two 
A

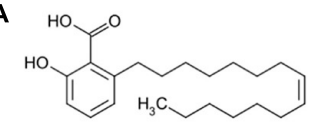

B $\alpha 1$ GlyR

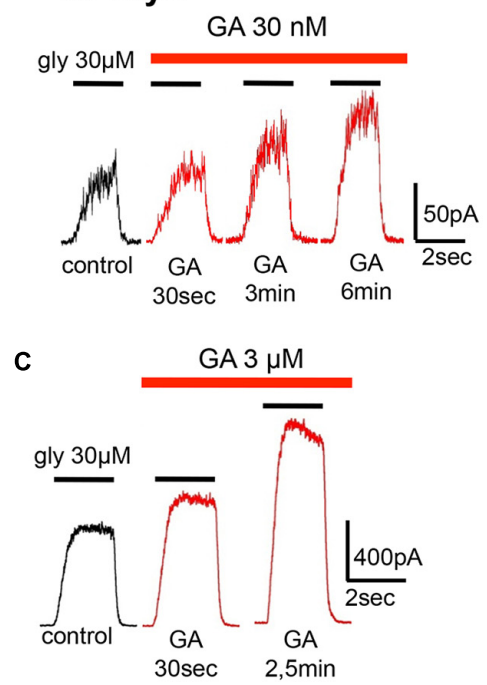

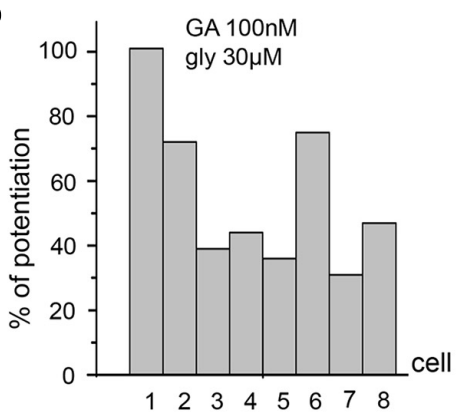

E

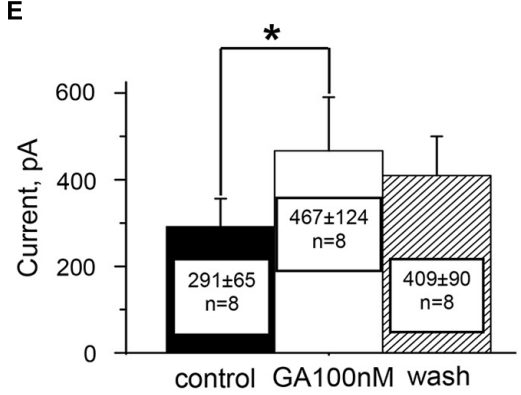

FIGURE 1 | Ginkgolic acid in nanomolar concentrations causes potentiation of $\mathrm{I}_{\text {gly }}$ mediated by homomeric $\alpha \mathbf{1}$ GlyRs expressed in CHO cells. (A) Structure of ginkgolic acids from G.biloba used in this study. (B) Whole-cell currents induced by $30 \mu \mathrm{M}$ glycine in control (black trace) and at the different time points of treatment of cells with $30 \mathrm{nM}$ of ginkgolic acid (red traces). For this and subsequent figures, black bars above the traces indicate the time of agonist application; red bars correspond to the duration of the ginkgolic acid application. Kgluconate pipette solution, holding potential $\left(V_{h}\right)=0 \mathrm{mV}$. (C) Examples of the whole-cell currents induced by $30 \mu \mathrm{M}$ glycine in control (black trace) and during application of $3 \mu \mathrm{M}$ ginkgolic acid (red traces). Note that at this concentration currents were already augmented $30 \mathrm{~s}$ after the beginning of ginkgolic acid application. Kgluconate pipette solution, $V_{\mathrm{h}}=0 \mathrm{mV}$. (D) Percentage of potentiation by $100 \mathrm{nM}$ ginkgolic acid (2 min of pre-application) of currents induced by $30 \mu \mathrm{M}$ glycine for eight individual cells expressing $\alpha 1 \mathrm{GlyRs}$. (E) Cumulative data on $\alpha 1$ GlyR-mediated current (glycine $30 \mu \mathrm{M}$ ) potentiation by $100 \mathrm{nM}$ of ginkgolic acid. Mean current amplitude (pA) \pm SEM from eight cells in control (black), after 2 min of ginkgolic acid (100 nM) application (white), and after washout (striped). Paired Student's $t$-test; asterisk $\left(^{*}\right)$ indicates significant difference, $p<0.05$.

parallel rectangular tubes $(100 \mu \mathrm{m} \times 100 \mu \mathrm{m})$ were positioned 40-50 $\mu \mathrm{m}$ above the recorded cell. The movement of the tubes was controlled by a computer-driven fast exchange system (SF 77A Perfusion Fast-Step, Warner, USA) allowing a 10-90\% solution exchange in 3-5 ms, as measured by open electrode controls (1/10 external solution/water).

In all experiments, the duration of the pulses of agonist was 2 s. The duration of ginkgolic acid application varied from $20 \mathrm{~s}$ to $6 \mathrm{~min}$. Cells with low input resistance ( $<150 \mathrm{MOhms})$ and a rapid run-down ( $>30 \%$ with repetitive application) were excluded from analysis.

\section{Data Analysis and Statistics}

All electrophysiological results were analyzed using PatchMaster (HEKA Electronik, Germany) software. Dose-response curves were constructed by fitting values obtained at different concentrations, after normalization. The responses to glycine concentration were fitted using the non-linear fitting routine of the Origin 7.5 software (OriginLabs, USA) with the Hill equation:

$$
I=1 /\left(1+\left(\mathrm{EC}_{50} /[\mathrm{A}]\right)^{n \mathrm{H}}\right),
$$

where $I$ is the normalized current amplitude induced by the agonist at concentration [A], $n_{\mathrm{H}}$ is the Hill coefficient and $\mathrm{EC}_{50}$ is the concentration at which a half-maximum response was induced.

Paired and unpaired Student's $t$-tests were used for statistical analysis. The data are expressed as the means \pm SEM.

\section{Drugs}

Ginkgolic acid (C15:1, HWI Analytic GmbH, Germany) was initially dissolved in pure DMSO and then diluted with control medium to the maximal final concentration of DMSO $0.016 \%$ in experiments with using $25 \mu \mathrm{M}$ ginkgolic acid. In test experiments, DMSO itself had no effects on the $\mathrm{I}_{\text {gly }}$ (data not shown; see also Mascia et al., 1996; Hall et al., 2004).

Other drugs were obtained from Tocris or Sigma-Aldrich (France).

\section{RESULTS}

\section{Low Concentrations of Ginkgolic Acid Potentiate $\alpha 1$ GlyRs}

To examine the effect of ginkgolic acid on the function of GlyRs, whole-cell currents in $\mathrm{CHO}$ cells expressing different receptor subunits were analyzed. We first investigated the effect 
of the acid on homomeric $\alpha 1$ GlyRs. To cells expressing human $\alpha 1$ GlyR, pulses of glycine of different concentrations and 2-s duration were applied before, during and after addition of ginkgolic acid. In contrast to the previously described inhibitory action of ginkgolides (Kondratskaya et al., 2002, 2004; Hawthorne et al., 2006), ginkgolic acid at relatively low concentrations (30 nM-3 $\mu \mathrm{M}$ ) strongly enhanced wholecell currents induced by sub-saturating $\left(\mathrm{EC}_{10}-\mathrm{EC}_{50}\right)$ glycine concentrations (Figures 1 and 2). In different cells the degree of potentiation induced by pre-application of $100 \mathrm{nM}$ ginkgolic acid during $2 \mathrm{~min}$ varied from 30 to $100 \%$ (mean $=51 \pm 10 \%, n=8$; Figure 1D) and the average $I_{\text {gly }}$ increased from $291 \pm 65$ to $467 \pm 124(n=8$; Figure 1E).

The time course of the action of $100 \mathrm{nM}$ ginkgolic acid on currents induced by repetitive application of sub-saturating glycine concentration is shown in Figure 2A. After obtaining the whole-cell configuration and stabilization of $\mathrm{I}_{\text {gly }}$ amplitude (first four pulses) the external solution was changed for the one containing $100 \mathrm{nM}$ of ginkgolic acid. Following the first $40 \mathrm{~s}$, $\mathrm{I}_{\text {gly }}$ was potentiated by $54 \%$ and reached a quasi-stable level after 2 min of ginkgolic acid application (see next three pulses). Then, after washing out for 3 min and partial recovery of $\mathrm{I}_{\text {gly }}$ amplitude, a second application of ginkgolic acid induced an even higher and more rapidly reversible potentiation (Figure 2A). Similar effects were observed in neuroblastoma cells expressing $\alpha 1$ GlyR (Figure 2B) and also in outside-out patches from $\mathrm{CHO}$ cells expressing homomeric $\alpha 1$ GlyRs (potentiation from 25 to $290 \%$, $n=5$, data not shown).

The kinetics of the potentiation depended on the concentration of ginkgolic acid; the effect of $30 \mathrm{nM}$ ginkgolic acid was observed after 2-3 min of treatment (Figure 1B) whereas $3 \mu \mathrm{M}$ ginkgolic acid caused an enhancement of $\mathrm{I}_{\text {gly }}$ by $>30 \%$ after only $30 \mathrm{~s}$ (Figure 1C). Higher concentrations of ginkgolic acid caused even more rapid enhancement of $\mathrm{I}_{\text {gly }}$. For instance, after 20-30 s of pre-treatment the mean potentiation induced by
$25 \mu \mathrm{M}$ ginkgolic acid was $153 \pm 25 \%(n=12)$, while $100 \mathrm{nM}$ ginkgolic acid during the same time augmented $\mathrm{I}_{\text {gly }}$ by only $26 \pm 8 \%$ ( $n=8$; data not shown).

Detailed analysis at different glycine concentrations revealed that ginkgolic acid potentiated currents induced by subsaturating doses of the agonist, while amplitudes of currents induced by saturating concentrations of glycine $(0.3-1 \mathrm{mM})$ were not affected but some acceleration of desensitization kinetics was observed (Figure 3A). Consequently, in the presence of ginkgolic acid, dose-response curves shifted to the left. Figure 3B represents an example of $\mathrm{EC}_{50}$ shift from $47 \mu \mathrm{M}$ in control to $28 \mu \mathrm{M}$ after application of $25 \mu \mathrm{M}$ ginkgolic acid. On average, $25 \mu \mathrm{M}$ ginkgolic acid caused a significant decrease in $\mathrm{EC}_{50}$ for glycine from $36 \pm 3 \mu \mathrm{M}(n=6)$ to $22 \pm 1.4 \mu \mathrm{M}(n=6$; $p<0.01)$. Similar shift in EC50 was observed also at using lower concentration of ginkgolic acid. For instance, pretreatment of cells with $3 \mu \mathrm{M}$ ginkgolic acid during 1-3 min caused a significant shift $(p<0.01)$ of $\mathrm{EC}_{50}$ from $36 \pm 6 \mu \mathrm{M}$ in control to $17 \pm 2 \mu \mathrm{M}(n=9)$ after application of the acid (data not shown).

These observations demonstrate that ginkgolic acid, albeit with slow kinetics, is capable of causing strong potentiation of $\alpha 1$ GlyR even in the nanomolar range of concentrations.

\section{Effect of Ginkgolic Acid on Heteromeric $\alpha 1 / \beta$ GlyRs}

Some antagonists of GlyRs exhibit different abilities to change the activities of homomeric and heteromeric receptors. For instance, the plant alkaloid picrotoxin more effectively inhibits homomeric GlyR than heretomeric $\alpha / \beta$ receptors (Pribilla et al., 1992; Pistis et al., 1997), while ginkgolide B more effectively antagonizes heteromeric GlyRs (Kondratskaya et al., 2005). To clarify whether ginkgolic acid exhibits the homo/hetero subunit selectivity we studied its action on heteromeric $\alpha 1 / \beta$ receptors.

Similarly to homomeric $\alpha 1$ GlyR, whole-cell currents induced by glycine concentrations below $\mathrm{EC}_{50}\left(\begin{array}{lll}30 & \mu \mathrm{M}\end{array}\right)$
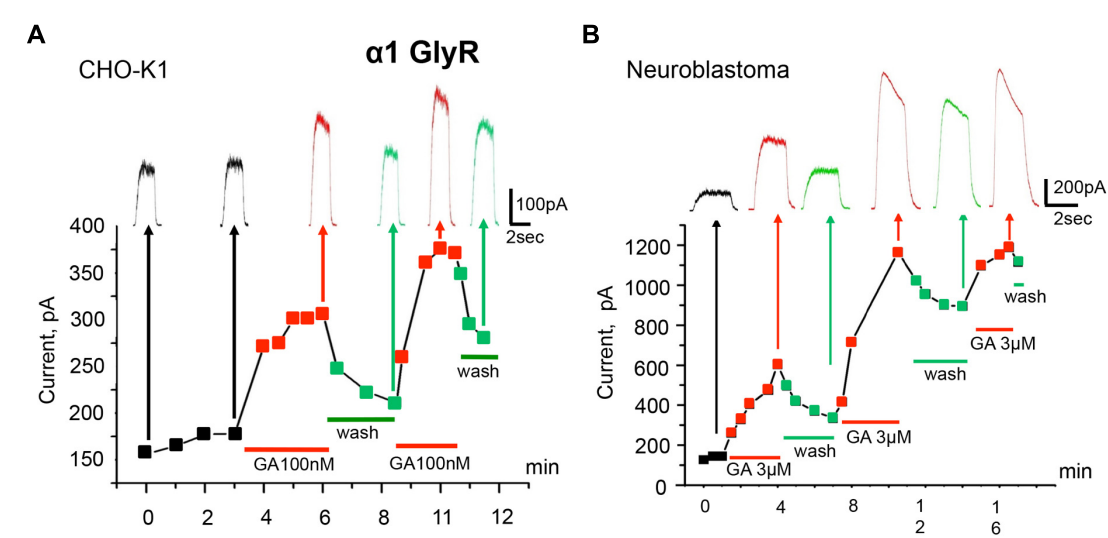

FIGURE 2 | Modulation of homomeric $\alpha \mathbf{1}$ GlyRs by ginkgolic acid. (A) Time course of the development of the effect of ginkgolic acid (100 nM) on whole-cell currents induced by $30 \mu \mathrm{M}$ glycine. Squares on the graph and traces above indicate amplitudes of the currents in control (black), in the presence of $100 \mathrm{nM}$ of ginkgolic acid (red) and during washout (green). Red and green bars below the graph correspond to the duration of ginkgolic acid application and washout. Kgluconate pipette solution, $V_{h}=0 \mathrm{mV}$. (B) Ginkgolic acid potentiates $\alpha 1$ GlyRs expressed in mouse neuroblastoma (N2a) cells. Time course of $I_{\text {gly }}$ changes during several application of the ginkgolic acid $(3 \mu \mathrm{M})$ to $\mathrm{N} 2 \mathrm{a}$ cells expressing $\alpha 1$ GlyR. Notice more than twofold increase in and partial recovery of $\mathrm{I}_{\mathrm{gly}}$ after the first two applications. Kgluconate pipette solution, $\mathrm{V}_{\mathrm{h}}=0 \mathrm{mV}$. 
A

a1 GlyR

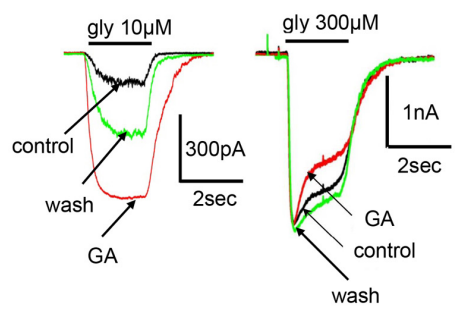

B

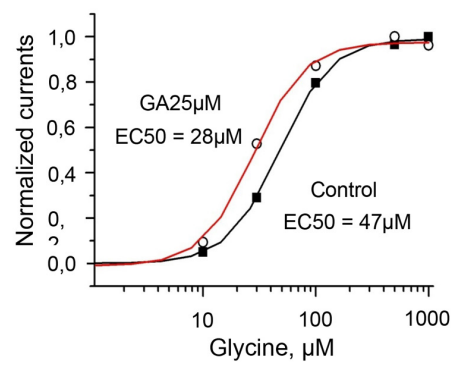

C

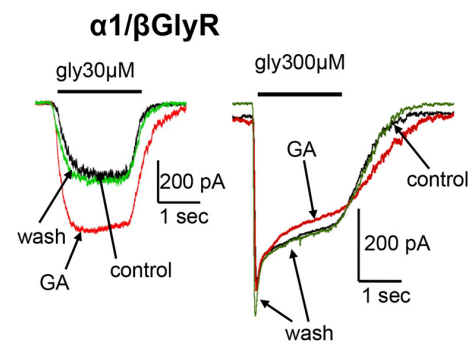

D

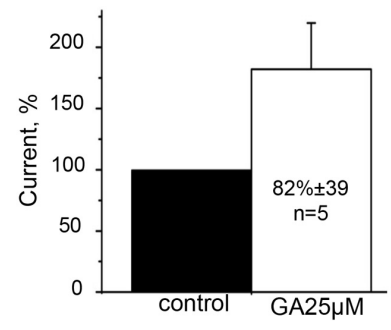

FIGURE 3 | Homomeric $\alpha 1$ and heteromeric $\alpha 1 / \beta$ GlyRs are similarly potentiated by ginkgolic acid. (A) Superimposed traces of whole-cell glycine-evoked currents induced by low (10 $\mu \mathrm{M}$; left) and high ( $300 \mu \mathrm{M}$; right) concentrations of glycine, in control (black), after ginkgolic acid application (25 $\mu \mathrm{M})$ (red) and after washout (green). Symmetrical CsCl pipette solution, $V_{h}=-30 \mathrm{mV}$. (B) Ginkgolic acid causes reduction in $\mathrm{EC}_{50}$ for glycine. Representative dose-response curve for glycine in control (black squares) and during application of $25 \mu \mathrm{M}$ ginkgolic acid (open circles). (C) Superimposed traces of whole-cell glycine-evoked currents induced by low (10 $\mu \mathrm{M}$; left) and high ( $300 \mu \mathrm{M}$; right) concentrations of glycine, in control (black), after ginkgolic acid application (25 $\mu \mathrm{M})$ (red) and after washout (green). Recording from the cell expressing heteromeric $\alpha 1 / \beta$ GlyRs. Symmetrical 'CsCl' pipette solution, $V_{h}=-30 \mathrm{mV}$. (D) Cumulative data. Mean percentage of $\alpha 1 / \beta$ GlyR-mediated current potentiation after treatment with ginkgolic acid $(25 \mu \mathrm{M})$.

were strongly potentiated by ginkgolic acid (Figure 3C, left). On average, currents induced by subsaturating glycine concentrations increased by $82 \pm 39 \%(n=5)$ in comparison with control (Figure 3D).

Similarly to homomeric a1 GlyRs, ginkgolic acid did not increase currents induced by application of saturated glycine concentrations $(0.3-1 \mathrm{mM})$ to heteromeric $\alpha 1 / \beta$ receptors (Figure 3C, right).

\section{Effect of Ginkgolic Acid on $\alpha 2$ GlyRs}

Before the analysis of the action of ginkgolic acid on GlyRs formed of $\alpha 2$ subunits, we estimated its $\mathrm{EC}_{50}$ by obtaining doseresponse curves. The $\mathrm{EC}_{50}$ to glycine varied from 24 to $69 \mu \mathrm{M}$ with a mean value $42 \pm 2 \mu \mathrm{M}(n=10$; data not shown), i.e., slightly higher than for $\alpha 1$ GlyRs.

In contrast to the action on $\alpha 1$ GlyRs, low concentrations of ginkgolic acid $(<10 \mu \mathrm{M})$ had no effect on the amplitude of $\mathrm{I}_{\text {gly }}$. At ginkgolic acid concentrations of $10 \mu \mathrm{M}$ or higher, a small inhibition of currents was observed. Thus, 10 and $25 \mu \mathrm{M}$ of ginkgolic acid inhibited $\alpha 2$ GlyRs by about $10 \pm 3 \%(n=8)$ and $-20 \pm 5 \%(n=11)$, respectively (Figure 4A). However, in many cells high doses of ginkgolic acid stimulated non-reversible run-down, which could be an additional reason for this small inhibition. At low concentrations $(1 \mu \mathrm{M})$ the effect of ginkgolic acid was not detectable; with a long application (5-6 mins) even the tendency to weak elevation of $I_{\text {gly }}$ was observed. This may result partially from a spontaneous run-up of responses during long-lasting whole cell recordings (data not shown, but see Fucile et al., 2000).

High concentrations of ginkgolic acid also caused a weak inhibition of heteromeric $\alpha 2 / \beta$ receptors $(-14 \pm 4 \%, n=9)$. Figure 4A summarizes the action of high ginkgolic acid doses on $\alpha 2$ and $\alpha 2 \beta$ receptors.

\section{Effect of Ginkgolic Acid on $\alpha 3$ GlyRs}

The human $\alpha 3$ GlyR subunit exists in two splice variants, $\alpha 3 \mathrm{~K}$ (short) and $\alpha 3 \mathrm{~L}$ (long), the last one bears an additional segment of 15 amino acids within the cytoplasmic TM3-TM4 loop (Breitinger et al., 2002) To analyze the action of ginkgolic acid on $\alpha 3$ GlyRs we selected $\alpha 3 \mathrm{~L}$ splice variant as its TM3TM4 insert is important for spatial structure stabilization of the cytoplasmic domain and it is involved in the regulation of GlyR channel gating (Breitinger et al., 2009).

Analysis of concentration dependencies showed that for GlyRs formed of this subunit the $\mathrm{EC}_{50}$ to glycine in control was $142 \pm 9.8 \mu \mathrm{M}(n=11$; data not shown), i.e., about threefold higher than for $\alpha 1$ and $\alpha 2$ GlyRs.

As illustrated in Figures 4B,C, the effect of ginkgolic acid $(25 \mu \mathrm{M})$ on the amplitude of whole-cell currents recorded from $\mathrm{CHO}$ cells expressing $\alpha 3$ GlyR was negligible. In more detail, after 20-40 sec of pre-treatment with ginkgolic acid, the currents induced by a concentration of glycine 'below $\mathrm{EC}_{50}$ ' $(100 \mu \mathrm{M})$ slightly decreased (Figure 4B, left), on average by $-9 \pm 2 \%$ 
A

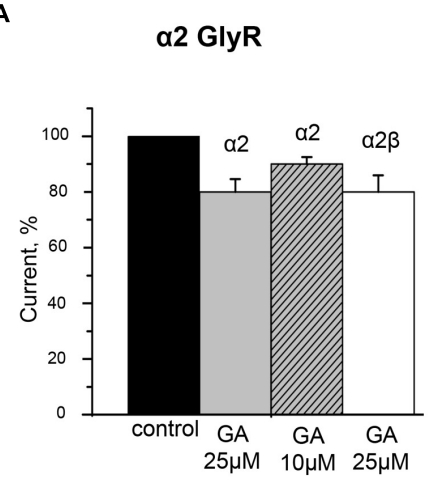

B

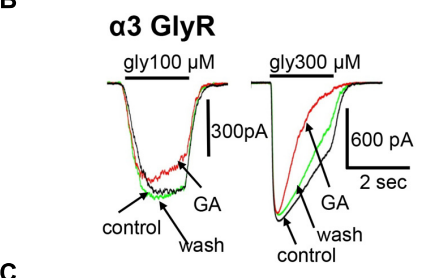

C

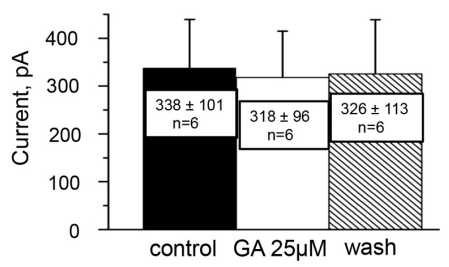

FIGURE 4 | Effect of ginkgolic acid on Igly mediated by homomeric $\alpha \mathbf{2}$ and $\alpha \mathbf{3}$ GlyRs and heteromeric $\alpha \mathbf{2} / \beta$ GlyRs. (A) Cumulative data. Mean percentage of the effect of $25 \mu \mathrm{M}$ ginkgolic acid on homomeric $\alpha 2$ GlyRs (light gray), heteromeric $\alpha 2 / \beta$ GlyRs (white colomn), and $10 \mu \mathrm{M}$ of ginkgolic acid on $\alpha 2$ GlyRs (striped). Glycine $30 \mu \mathrm{M}$ was applied. Data from 7 to 12 cells for each case. (B) Superimposed traces of glycine-evoked currents induced by low for this subunit (100 $\mu \mathrm{M}$; left) and high (300 $\mu \mathrm{M}$; right) concentrations of glycine, in control (black), after ginkgolic acid application (red) and after washout (green). Symmetrical 'CsCl' pipette solution, $V_{h}=-30 \mathrm{mV}$. (C) Summary of the data on the effect of ginkgolic acid on the $\alpha 3$-long subunit of GlyR. Mean amplitudes of currents (pA) $\pm \mathrm{SEM}$ induced by $100 \mu \mathrm{M}$ glycine from six cells in control (black), during ginkgolic acid application (white), and after washout (striped).

(from -4 to $-11 \% ; n=4$ ); two other cells showed no effect and in one cell a weak potentiation $(+4 \%)$ was observed. For this concentration, mean currents in control, in the presence of ginkgolic acid and after washout were, respectively, $338 \pm 101$ pA, $318 \pm 96 \mathrm{pA}$, and $326 \pm 113 \mathrm{pA}(n=6$; Figure 4C).

Similarly to its action on $\alpha 1$ and $\alpha 2$ subunits, ginkgolic acid accelerated the desensitization kinetics of currents induced by application of saturated glycine concentrations $(\geq 300 \mu \mathrm{M}$; Figure 4B, right).

These data indicate that ginkgolic acid, even at high doses, is not capable of potentiating the function of $\alpha 2$ and $\alpha 3$ GlyRs.

\section{Effect of Ginkgolic Acid on GABA $A_{A}$ Rs}

We further analyzed the action of ginkgolic acid on GABA receptors expressed in $\mathrm{CHO}$ cells. Its effect was studied on the most widespread in mammalian brain $\mathrm{GABA}_{\mathrm{A}} \mathrm{R}$ combination - $\alpha 1 / \beta 2 / \gamma 2$ (Olsen and Sieghart, 2008). We assume that all cells that demonstrated GABA-evoked currents expressed on their surface $\alpha 1 / \beta 2 / \gamma 2$ receptors, as it was shown before that $\alpha 1 \gamma 2, \beta 2 \gamma 2$ and homomeric receptors are retained within the endoplasmic reticulum (Connolly et al., 1996; Gorrie et al., 1997). Moreover, cells transfected only with $\beta 2$ subunits do not produce ionic currents (Connolly et al., 1996) or surface staining (Taylor et al., 1999).

Analysis of concentration dependencies revealed that the $\mathrm{EC}_{50}$ of GABA for $\mathrm{GABA}_{\mathrm{A}}$ Rs in control solution was $11 \pm 1 \mu \mathrm{M}$ (data not shown). The action of ginkgolic acid was tested on 16 cells at using concentration of GABA close to $\mathrm{EC}_{50}(10 \mu \mathrm{M})$ and on three cells using concentration of GABA close to $\mathrm{EC}_{10}(1 \mu \mathrm{M})$. After $20-40 \mathrm{~s}$ of treatment with ginkgolic acid $(25 \mu \mathrm{M})$, we did not observe any changes in GABA-evoked currents, either with $\mathrm{EC}_{10}$ (Figure 5A) or with $\mathrm{EC}_{50}$ (Figure 5B) concentrations of GABA. For $10 \mu \mathrm{M}$ GABA the mean currents in control, after ginkgolic

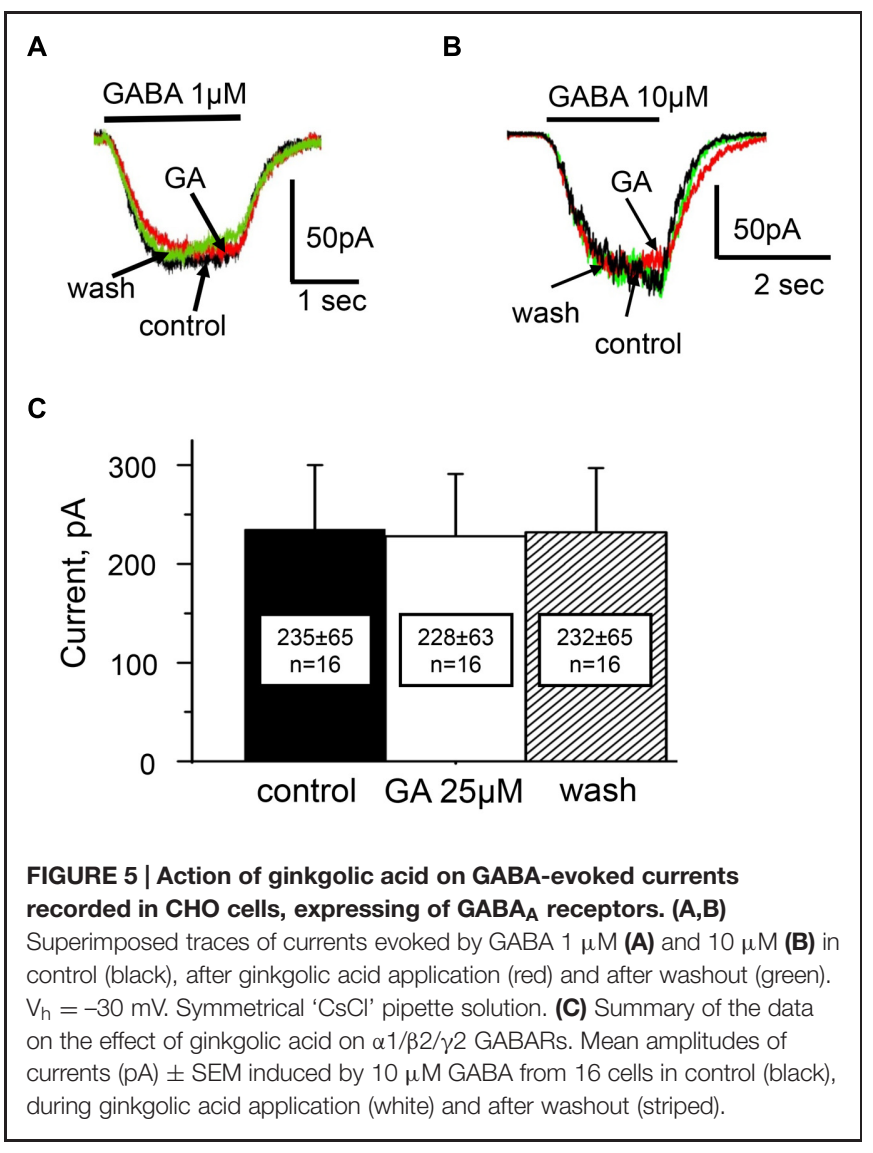

acid application and after washout were $235 \pm 65 \mathrm{pA}, 228 \pm 63$ $\mathrm{pA}$, and $232 \pm 65 \mathrm{pA}(n=16)$, respectively (Figure $5 \mathrm{C})$.

Thus, similarly to the $\alpha 3$ GlyR, there was no significant difference between GABA-induced currents for the $\alpha 1 / \beta 2 / \gamma^{2}$ 
combination of $\mathrm{GABA}_{\mathrm{A}} \mathrm{Rs}$ before and after ginkgolic acid $(25 \mu \mathrm{M})$ application.

\section{Amino Acids Involved in the Modulation of GlyRs by Ginkgolic Acid}

Finally, we searched for the residues responsible for the different actions of ginkgolic acid on $\alpha 1$ and $\alpha 2$ GlyR subunits. Recent studies have identified several residues involved in allosteric modulation of different GlyR subunits (Xiong et al., 2011; Yevenes and Zeilhofer, 2011a). Among them are the S296 residue in the third TM3, as well as alanine 52 in the extracellular region and glycine 254 in the TM2 domain.

As some parts of the chemical organization of endocannabinoids and ginkgolic acid show high similarity we investigated whether there are also similarities of functional effects. Indeed, both compounds produce potentiation of $\alpha 1$ GlyR subunits. Molecular sites for allosteric control of GlyRs by the endocannabinoid have been identified (Yevenes and Zeilhofer, 2011a). It has been shown that substitution in the $\alpha 2$ subunit of residues T59, A261, and A303 (Figure 6A) for corresponding residues from the $\alpha 1$ subunit (A52, G254, and S296) converts the effect of $\mathrm{N}$-arachidonoyl-glycine from inhibition to potentiation (Yevenes and Zeilhofer, 2011a).

In order to check whether the same amino acid residues are indispensable for positive modulation of $\alpha 1$ GlyR by ginkgolic acid we performed T59A/A261G/A303S substitution in $\alpha 2$ subunit (Figure 6A) and studied the effect of ginkgolic acid on currents mediated by this $\alpha 2$ GlyR mutant. Ginkgolic acid applied to $\mathrm{CHO}$ cells expressing $\alpha 2$ T59A/A261G/A303S subunits caused potentiation of responses to glycine, similar to those observed for $\alpha 1$ GlyR (Figure 6B). After pre-application for 1-2 mins of $3 \mu \mathrm{M}$ ginkgolic acid, currents induced by non-saturating glycine concentrations $(30 \mu \mathrm{M})$ increased in different cells in the wide range from 25 to $300 \%$ (Figure 6D), with a mean value of $95 \pm 21 \%(n=12)$.

Analysis of concentration dependencies revealed that the sensitivity of the mutant GlyR to glycine was weaker than that of WT $\alpha 2$ GlyR. In control conditions, the glycine $\mathrm{EC}_{50}$ s for $\alpha 2$ mutant receptors varied from 56 to $238 \mu \mathrm{M}$. In the presence of $3 \mu \mathrm{M}$ ginkgolic acid, dose-response curves showed a distinct leftshift $\left(\mathrm{EC}_{50}\right.$ values varied from 31 to $\left.118 \mu \mathrm{M}\right)$. Thus, in the cell illustrated in Figure 6C, in control conditions $\mathrm{EC}_{50}$ was $157 \mu \mathrm{M}$ and it became $69 \mu \mathrm{M}$ in the presence of ginkgolic acid. On average, ginkgolic acid caused a significant $(p<0.05)$ decrease in $\mathrm{EC}_{50}$ from $119 \pm 16 \mu \mathrm{M}$ in control to $76 \pm 9 \mu \mathrm{M}(n=12)$ in the presence of $3 \mu \mathrm{M}$ ginkgolic acid.

Marked potentiation was observed following the application of ginkgolic acid in the nanomolar range of concentrations. As illustrated in Figure 6E the time-course and amplitude of $\mathrm{I}_{\mathrm{gly}}$ potentiation induced by $100 \mathrm{nM}$ ginkgolic acid were similar to those for $\alpha 1$ GlyR.

All together, these observations demonstrate that after mutation of three residues (T59A/A261G/A303S) in the $\alpha 2$
A

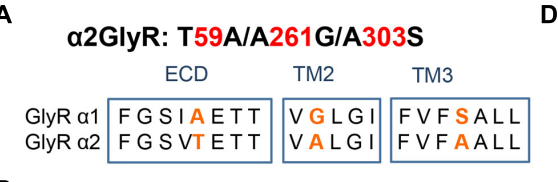

B

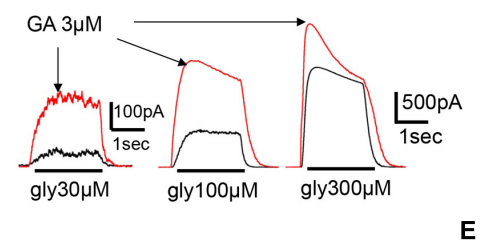

E
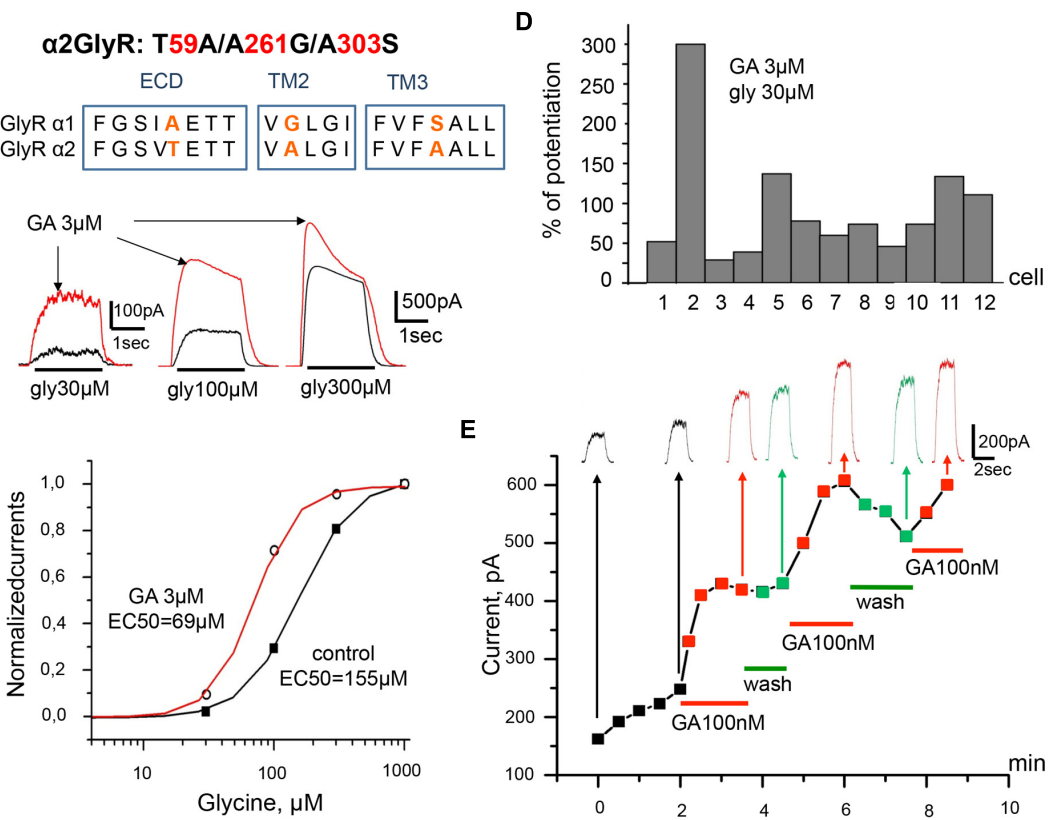

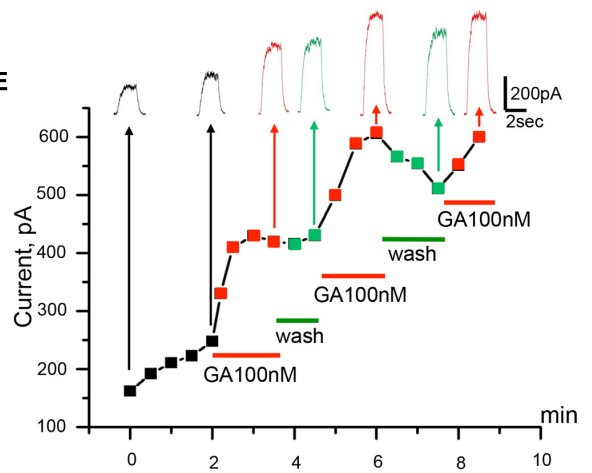

FIGURE 6 | Ginkgolic acid causes potentiation of $I_{\text {gly }}$ on cells expressing the mutant $\alpha 2$ (T59A/A261G/A303S) GlyRs. (A) Primary sequence alignment of $\alpha 1$ and $\alpha 2$ GlyR subunits in the extracellular loop, TM2 and TM3 domains; substituted residues are in red. (B) Superimposed traces of glycine-evoked currents induced by different glycine concentrations $(30,100,300 \mu \mathrm{M})$ in control (black) and after ginkgolic acid $(3 \mu \mathrm{M})$ application (red). Kgluconate pipette solution, $V_{h}=0 \mathrm{mV}$. (C) Ginkgolic acid causes a reduction in $\mathrm{EC}_{50}$ for glycine. Normalized dose-response curves for glycine in control (black squares) and during application of $3 \mu \mathrm{M}$ of ginkgolic acid (open circles). (D) Percentage of potentiation of glycine (30 $\mu \mathrm{M})$ evoked currents after ginkgolic acid ( $3 \mu \mathrm{M})$ application for eight individual cells expressing a2 (T59A/A261G/A303S) GlyRs. (E) Example of the time course of the development of the ginkgolic acid effect ( $3 \mu \mathrm{M})$ on the amplitude of the ionic currents mediated by a2 (T59A/A261G/A303S) GlyRs; glycine $30 \mu \mathrm{M}$ was applied. Kgluconate pipette solution, $\mathrm{V}_{\mathrm{h}}=0 \mathrm{mV}$. 
subunit the effect of ginkgolic acid on the receptor became similar to that observed on $\alpha 1$ GlyR.

\section{DISCUSSION}

In this study we have shown that GlyRs are modulated by ginkgolic acid in a subunit-specific manner. After pre-application of ginkgolic acid ( $0.5-6 \mathrm{~min}), \mathrm{I}_{\mathrm{gly}}$ mediated by $\alpha 1$ GlyRs expressed in $\mathrm{CHO}$ and neuroblastoma cells were strongly potentiated. This effect was observed at nanomolar ginkgolic acid concentration (30-100 nM). High doses of ginkgolic acid $(25 \mu \mathrm{M})$ caused a small inhibition of $\alpha 2$ GlyRs, while there was no detectible effect of ginkgolic acid on amplitudes of currents mediated by $\alpha 3$ GlyRs or on $\mathrm{GABA}_{\mathrm{A}}$ Rs composed of $\alpha 1 / \beta 1 / \gamma 2$ subunits. These observations indicate that low concentrations of ginkgolic acid highly specifically potentiate $\alpha 1$ GlyRs.

The effects of ginkgolic acid on $\alpha 1$ GlyRs exhibit the following features. Firstly, potentiation is accompanied by significant leftshifts of dose-response curves and a decrease in $\mathrm{EC}_{50}$ values, suggesting modulation of gating properties of $\alpha 1$ GlyR channels. Analysis of dose-response curves demonstrated that 25 and $3 \mu \mathrm{M}$ of ginkgolic acid caused a similar shift in $\mathrm{EC}_{50}$ : respectively, from 36 to $22 \mu \mathrm{M}$ and form 36 to $17 \mu \mathrm{M}$. This allows to suggest that the maximal potentiation of $\alpha 1$ GlyR can be achieved even at relatively low doses of the acid.

Secondly, potentiation develops slowly, on a time scale of minutes, and the strength of the effect depends on the concentration of ginkgolic acid. During application of $30 \mathrm{nM}$ ginkgolic acid the onset of potentiation was observed only after 2-3 min, while high concentrations $(25 \mu \mathrm{M})$ caused potentiation by more than $150 \%$ after only $30 \mathrm{~s}$ of ginkgolic acid presence in the external solution.

Recovery of glycine-evoked currents after potentiation of $\alpha 1$ GlyRs by ginkgolic acid, developed slowly, usually not being complete, in the time range of minutes. This could occur for two main reasons. First, the slow unbinding rate of ginkgolic acid from the potentiating site of the receptor situated in a hydrophobic membrane environment. Very low concentrations of the drug could accumulate at binding sites and produce longlasting enhancement, similar to the inhibitory effects of lipophilic blockers of GlyR (Islam and Lynch, 2012). Second, spontaneous increase in $\mathrm{I}_{\mathrm{gly}}$, as it has been previously demonstrated that during long-lasting whole-cell recordings the $\mathrm{EC}_{50}$ of GlyRs for glycine spontaneously increases (Fucile et al., 2000). While this spontaneous enhancement of currents was clearly distinguishable from effects of ginkgolic acid (Supplementary Figure S1), it could contribute to the irreversible increase.

Ginkgolic acid at very high doses $(>10 \mu \mathrm{M})$ caused a weak inhibition of whole-cell currents mediated by receptors formed of $\alpha 2$ subunits, without modulating the function of $\alpha 3$ GlyRs and $\mathrm{GABA}_{\mathrm{A}} \mathrm{R}$. Moreover, at $1 \mu \mathrm{M}$ ginkgolic acid was not able to modulate $\alpha 2$ GlyRs, confirming its selectivity to $\alpha 1$ GlyRs.

In order to further investigate this subunit-specific effect of ginkgolic acid we have focused on possible interaction sites for this compound inside different GlyR domains. In previous studies it has been shown that most of the residues that are responsible for GlyR modulation by ions, cannabinoids, alcohols, and anesthetics are located in the extracellular domain, in the TM2 and TM3 domains (Mihic et al., 1997; Lynch et al., 1998; Maksay et al., 2009; Yevenes and Zeilhofer, 2011b).

It has been demonstrated that extracellularly localized amino acid 52 of the $\alpha$ subunit is responsible for the differences in the ethanol sensitivity of GlyRs composed of homomeric $\alpha 1$ and $\alpha 2$ subunits (Mascia et al., 1996). Specifically, $\alpha 1$ GlyRs were more sensitive to the action of the ethanol than were $\alpha 2$ GlyRs or the mutant $\alpha 1$ (A52S) receptors. Situated in TM3 domain, residue S296 was found to be crucial for GlyR potentiation by THC, the major psychoactive component of marijuana (Xiong et al., 2011). THC more effectively potentiated currents mediated by GlyR $\alpha 1$ subunits than the currents mediated by $\alpha 2$ subunits. Mutants of $\alpha 1$ subunits in which serine 296 was substituted for alanine showed a decrease in the potentiation magnitude (Xiong et al., 2012).

Subunit-specific modulation of GlyRs has also been demonstrated for the endocannabinoid $\mathrm{N}$-arachidonoyl-glycine and synthetic CB1 and/or CB2 receptor ligands (HU-210, WIN $55,212-2$ ), which potentiate $\alpha 1$ GlyR and inhibit $\alpha 2$ GlyR (Yang et al., 2008). Searching for sites involved in positive modulation of GlyR by endocannabinoids it was revealed that substitution of three amino acids in $\alpha 2$ subunits for corresponding amino acids from $\alpha 1$ subunits T59A/A261G/A303S can convert the inhibitory effect of NA-Gly into potentiation (Yevenes and Zeilhofer, 2011a). Based on the similarity of NA-Gly and ginkgolic acid in the GlyR modulation profile we have suggested that the same amino acid residues could be responsible for $\alpha 1$ GlyR potentiation by ginkgolic acid.

Indeed, application of ginkgolic acid to cells expressing Q2 T59A/A261G/A303S subunits resulted in (i) an increase in responses to low concentrations of glycine; (ii) a slow development of the effect, similarly as for $\alpha 1$ GlyR. This augmentation effect was observed at as low as $100 \mathrm{nM}$ of ginkgolic acid. Our results reinforce the important role of these amino acids for specific modulation of $\alpha 1$ GlyR. The molecular mechanisms underlying the interaction of drugs with these residues and processes determining specificity of their action needs further analysis.

In contrast to selective potentiation of alpha $1 \mathrm{GlyR}$, ginkgolic acid caused similar acceleration of desensitization of all GlyR subunits (see, for instance, Figures 3 and $\mathbf{4}$ ). In line with previous observations (Breitinger et al., 2002) it suggests that regulation of ion channel activation and desensitization can involve different domains. The molecular determinants of desensitization may involve extracellular and TMs or interface between them (Bouzat et al., 2008; Wang and Lynch, 2011), as well as TM1-TM2 (Breitinger et al., 2001) and TM2-TM3 (Nikolic et al., 1998; Breitinger et al., 2002; Meiselbach et al., 2014) cytoplasmic domains. A recent study presented compelling experimental and modeling analysis of this phenomenon demonstrating that the internal end of TM3 and TM1-TM2 linker control desensitization (Gielen et al., 2015). As these parts of molecular sequences are identical for all GlyR subunits, in a view of the study by Gielen et al. (2015), one can suggest that regulation of desensitization by ginkgolic acid may be developed at this level. 
Being lipophilic ginkgolic acid can penetrate plasma membrane and interact with various intracellular targets (Fukuda et al., 2009; Lu et al., 2012; Ma et al., 2015) causing regulation of receptor functioning through the intracellular pathways. Thus, activation of protein phosphatase 2C (PP2C) by ginkgolic acid and, consequently, stimulation of neuronal death in cell cultures has been previously demonstrated (Ahlemeyer et al., 2001). However, ginkgolic acid caused effects on PP2C at very high concentrations (>100 $\mu \mathrm{M}$ ) (Ahlemeyer et al., 2001), while the effects in our experiments effects were observed at $100 \mathrm{nM}$, i.e. 1000x less concentration.

We also performed testing of ginkgolic acid action on outsideout patches from cells expressing $\alpha 1$ GlyRs. This configuration should accelerate washing out of intracellular components and eliminate potentiation. However, modulation was very similar to that seen during whole-cell recordings. In addition, ginkgolic acid potentiated mutant $\alpha 2$ GlyRs suggesting its interaction with receptor proteins.

Although these observations reduce the assumption of regulation through the intracellular pathways, this possibility is not excluded. Careful analysis in a separate study using the insideout configuration and other approaches is necessary to clarify this question.

Several previous studies have demonstrated that cannabinoids and endocannabinois cause modulation of GyR function (Lozovaya et al., 2011). The most effective is a natural component of marijuana, THC, which at nanomolar concentrations (beginning from $30 \mathrm{nM}$ ) caused potentiation of $\alpha 1$ and $\alpha 3$ GlyR subunits with weak augmentation of $\alpha 2$ GlyR-mediated currents (Xiong et al., 2011). However, effects of other compounds from this family are complicated, as they cause direct modulation of voltage-gated and receptor-operated ion channels (see reviews, $\mathrm{Oz}, 2006)$. While the action of gingkolic acid on other receptors, ion channels, and synaptic networks needs future analysis, the observations presented here suggest that this compound acts as a specific enhancer of $\alpha 1$ GlyR subunits, with the threshold of potentiation in the range of $30 \mathrm{nM}$.

A large variety of evidence indicates that GlyR subtypes are differentially distributed in the nervous system. GlyR functions depend on subunit composition, subsynaptic localization, and

\section{REFERENCES}

Ahlemeyer, B., Selke, D., Schaper, C., Klumpp, S., and Krieglstein, J. (2001). Ginkgolic acids induce neuronal death and activate protein phosphatase type-2C. Eur. J. Pharmacol. 430, 1-7. doi: 10.1016/S0014-2999(01) 01237-7

Aroeira, R. I., Ribeiro, J. A., Sebastião, A. M., and Valente, C. A. (2011). Age-related changes of glycine receptor at the rat hippocampus: from the embryo to the adult. J. Neurochem. 118, 339-353. doi: 10.1111/j.1471-4159.2011.07197.x

Balansa, W., Islam, R., Gilbert, D. F., Fontaine, F., Xiao, X., Zhang, H., et al. (2013). Australian marine sponge alkaloids as a new class of glycine-gated chloride channel receptor modulator. Bioorg. Med. Chem. 21, 4420-4425. doi: 10.1016/j.bmc.2013.04.061

Betz, H., and Laube, B. (2006). Glycine receptors: recent insights into their structural organization and functional diversity. J. Neurochem. 97, 1600-1610. doi: 10.1111/j.1471-4159.2006.03908.x

Bouzat, C., Bartos, M., Corradi, J., and Sine, S. M. (2008). The interface between extracellular and transmembrane domains of homomeric cys-loop receptors activation mode, they are involved in the control of many motor and sensory pathways, including those necessary for audition, vision, respiration and nociception (Kirsch, 2006; Harvey et al., 2009; Dutertre et al., 2012; Zeilhofer et al., 2012). Thus, $\alpha 1$ GlyRs are primary localized in adult spinal cord, being responsible for movement and muscle tone control (Kneussel and Betz, 2000; Lynch, 2004); $\alpha 2$ GlyRs are important for embryonic brain development (Kneussel and Betz, 2000) and visual perception (Haverkamp et al., 2004). These receptors are dominantly expressed in prenatal brain, but their number dramatically decreases between birth and the third postnatal week (Sato et al., 1992). At the same period, the level of $\alpha 1$ GlyRs increases and they become widely distributed in spinal cord, retina, and brainstem nuclei (Malosio et al., 1991; Sato et al., 1992; Greferath et al., 1994; Zeilhofer et al., 2012). GlyRs are differentially expressed in hippocampus and their subcellular localization and subunit composition change over development (Aroeira et al., 2011). Thus, our observations on subunit-specific modulation of GlyRs by ginkgolic acid might be relevant for specific regulation of the physiological functions mediated by GlyRs in pathological conditions.

\section{ACKNOWLEDGMENTS}

This study was supported for GM by a Fellowship from the French Ministry of Foreign Affairs and for SB by the European Union Seventh Framework Programme under grant agreement no. HEALTH-F2-2008-202088 ("Neurocypres" Project) and the Alzheimer's Association research grant NESAD-12-242486.

\section{SUPPLEMENTARY MATERIAL}

The Supplementary Material for this article can be found online at: http://journal.frontiersin.org/article/10.3389/fnmol. 2015.00064

Figure S1 | Differences in the time course of elevation of current amplitudes induced by glycine $(30 \mu \mathrm{M})$ at spontaneous run up and during application of $100 \mathrm{nM}$ ginkgolic acid.

governs open-channel lifetime and rate of desensitization. J. Neurosci. 28, 7808-7819. doi: 10.1523/JNEUROSCI.0448-08.2008

Breitinger, H. G., Villmann, C., Becker, K., and Becker, C. M. (2001). Opposing effects of molecular volume and charge at the hyperekplexia site alpha $1(\mathrm{P} 250)$ govern glycine receptor activation and desensitization. J. Biol. Chem. 276, 29657-29663. doi: 10.1074/jbc.M10044 6200

Breitinger, H.-G., Villmann, C., Melzer, N., Rennert, J., Breitinger, U., Schwarzinger, S., et al. (2009). Novel regulatory site within the TM34 loop of human recombinant $\alpha 3$ glycine receptors determines channel gating and domain structure. J. Biol. Chem. 284, 28624-28633. doi: 10.1074/jbc.M109.043174

Breitinger, H.-G., Villmann, C., Rennert, J., Ballhausen, D., and Becker, C.-M. (2002). Hydroxylated residues influence desensitization behaviour of recombinant alpha3 glycine receptor channels. J. Neurochem. 83, 30-36. doi: 10.1046/j.1471-4159.2002.01109.x

Bueno, O. F., Robinson, L. C., Alvarez-Hernandez, X., and Leidenheimer, N. J. (1998). Functional characterization and visualization of a GABA A 
receptor-GFP chimera expressed in Xenopus oocytes. Mol. Brain Res. 59, 165177. doi: 10.1016/S0169-328X(98)00129-6

Burzomato, V., Groot-Kormelink, P. J., Sivilotti, L. G., and Beato, M. (2003). Stoichiometry of recombinant heteromeric glycine receptors revealed by a pore-lining region point mutation. Recept Channels 9, 353-361.

Connolly, C. N., Krishek, B. J., McDonald, B. J., Smart, T. G., and Moss, S. J. (1996). Assembly and cell surface expression of heteromeric and homomeric gamma-aminobutyric acid type A receptors. J. Biol. Chem. 271, 89-96. doi: 10.1074/jbc.271.1.89

Dlugaiczyk, J., Singer, W., Schick, B., Iro, H., Becker, K., Becker, C. M., et al. (2008). Expression of glycine receptors and gephyrin in the rat cochlea. Histochem. Cell Biol. 129, 513-523. doi: 10.1007/s00418-008-0387-x

Durisic, N., Godin, A. G., Wever, C. M., Heyes, C. D., Lakadamyali, M., and Dent, J. (2012). Stoichiometry of the human glycine receptor revealed by direct subunit counting. J. Neurosci. 32, 12915-12920. doi: 10.1523/JNEUROSCI.205012.2012

Dutertre, S., Becker, C.-M., and Betz, H. (2012). Inhibitory glycine receptors: an update. J. Biol. Chem. 287, 40216-40223. doi: 10.1074/jbc.R112.408229

Fucile, S., De Saint Jan, D., Prado de Carvalho, L., and Bregestovski, P. (2000). Fast potentiation of glycine receptor channels by intracellular calcium in neurons and transfected cell. Neuron 28, 571-583. doi: 10.1016/S0896-6273(00)00134-3

Fukuda, I., Ito, A., Hirai, G., Nishimura, S., Kawasaki, H., Saitoh, H., et al. (2009). Ginkgolic acid inhibits protein SUMOylation by blocking formation of the E1-SUMO intermediate. Chem. Biol. 16, 133-140. doi: 10.1016/j.chembiol.2009.01.009

Fuzzati, N., Pace, R., and Villa, F. (2003). A simple HPLC-UV method for the assay of ginkgolic acids in Ginkgo biloba extracts. Fitoterapia 74, 247-256. doi: 10.1016/S0367-326X(03)00040-6

Gielen, M., Thomas, P., and Smart, T. G. (2015). The desensitization gate of inhibitory Cys-loop receptors. Nat. Commun. 6, 6829. doi: 10.1038/ncomms7829

Gorrie, G. H., Vallis, Y., Stephenson, A., Whitfield, J., Browning, B., Smart, T. G., et al. (1997). Assembly of GABAA receptors composed of a1 and b2 subunits in both cultured neurons and fibroblasts. J. Neurosci. 17, 6587-6596.

Greferath, U., Brandstätter, J., Wässle, H., Kirsch, J., Kuhse, J., and Grünert, U. (1994). Differential expression of glycine receptor subunits in the retina of the rat: a study using immunohistochemistry and in situ hybridization. Vis. Neurosci. 11, 721-729. doi: 10.1017/S0952523800003023

Grudzinska, J., Schemm, R., Haeger, S., Nicke, A., Schmalzing, G., Betz, H., et al. (2005). The beta subunit determines the ligand binding properties of synaptic glycine receptors. Neuron 45, 727-739. doi: 10.1016/j.neuron.2005.01.028

Hall, A. C., Turcotte, C. M., Betts, B. A., Yeung, W. Y., Agyeman, A. S., and Burk, L. A. (2004). Modulation of human GABA A and glycine receptor currents by menthol and related monoterpenoids. Eur. J. Pharmacol. 506, 9-16. doi: 10.1016/j.ejphar.2004.10.026

Harvey, R. J., Depner, U. B., Wässle, H., Ahmadi, S., Heindl, C., Reinold, H., et al. (2004). GlyR alpha3: an essential target for spinal PGE2-mediated inflammatory pain sensitization. Science 304, 884-887. doi: 10.1126/science. 1094925

Harvey, V. L., Caley, A., Müller, U. C., Harvey, R. J., and Dickenson, A. H. (2009). A selective role for $\alpha 3$ subunit glycine receptors in inflammatory pain. Front. Mol. Neurosci. 2:14. doi: 10.3389/neuro.02.014.2009

Haverkamp, S., Müller, U., Zeilhofer, H. U., Harvey, R. J., and Wässle, H. (2004). Diversity of glycine receptors in the mouse retina: localization of the alpha2 subunit. J. Comp. Neurol. 477, 399-411. doi: 10.1002/cne.20267

Hawthorne, R., Cromer, B., Ng, H., Parker, M. W., and Lynch, J. W. (2006). Molecular determinants of ginkgolide binding in the glycine receptor pore. J. Neurochem. 98, 395-407. doi: 10.1111/j.1471-4159.2006.03875.x

Hecker, H., Johannisson, R., Koch, E., and Siegers, C. P. (2002). In vitro evaluation of the cytotoxic potential of alkylphenols from Ginkgo biloba L. Toxicology 177 167-177. doi: 10.1016/S0300-483X(02)00189-0

Heinze, L., Harvey, R. J., and Haverkamp, S. (2007). Diversity of glycine receptors in the mouse retina: localization of the alpha 4 subunit. J. Comp. Neurol. 500, 693-707.

Islam, R., and Lynch, J. W. (2012). Mechanism of action of the insecticides, lindane and fipronil, on glycine receptor chloride channels. Br. J. Pharmacol. 165, 2707-2720. doi: 10.1111/j.1476-5381.2011.01722.x

Jaggy, H., and Koch, E. (1997). Chemistry and biology of alkylphenols from Ginkgo biloba L. Pharmazie 52, 735-738.
Kalkunte, S. S., Singh, A. P., Chaves, F. C., Gianfagna, T. J., Pundir, V. S., Jaiswal, A. K., et al. (2007). Antidepressant and antistress activity of GC-MS characterized lipophilic extracts of Ginkgo biloba leaves. Phytother. Res. 21, 1061-1065. doi: 10.1002/ptr.2212

Kim, H. J., Lee, B. H., Choi, S. H., Jung, S. W., Kim, H. S., Lee, J. H., et al. (2015). Differential effects of quercetin glycosides on GABAC receptor channel activity. Arch. Pharm. Res. 38, 108-114. doi: 10.1007/s12272-014-0409-2

Kirsch, J. (2006). Glycinergic transmission. Cell Tissue Res. 326, 535-540. doi: 10.1007/s00441-006-0261-x

Kneussel, M., and Betz, H. (2000). Clustering of inhibitory neurotransmitter receptors at developing postsynaptic sites: the membrane activation model. Trends Neurosci. 23, 429-435. doi: 10.1016/S0166-2236(00)01627-1

Kondratskaya, E. L., Betz, H., Krishtal, O., and Laube, B. (2005). The beta subunit increases the ginkgolide $B$ sensitivity of inhibitory glycine receptors. Neuropharmacology 49, 945-951. doi: 10.1016/j.neuropharm.2005.07.001

Kondratskaya, E. L., Fisyunov, A. I., Chatterjee, S. S., and Krishtal, O. (2004). Ginkgolide B preferentially blocks chloride channels formed by heteromeric glycine receptors in hippocampal pyramidal neurons of rat. Brain Res. Bull. 63, 309-314. doi: 10.1016/j.brainresbull.2004.03.007

Kondratskaya, E. L., Lishko, P. V., Chatterjee, S. S., and Krishtal, O. (2002). BN52021, a platelet activating factor antagonist, is a selective blocker of glycinegated chloride channel. Neurochem. Int. 40, 647-653. doi: 10.1016/S01970186(01)00109-7

Langosch, D., Becker, C. M., and Betz, H. (1990). The inhibitory glycine receptor: a ligand-gated chloride channel of the central nervous system. Eur. J. Biochem. 194, 1-8. doi: 10.1111/j.1432-1033.1990.tb19419.x

Langosch, D., Thomas, L., and Betz, H. (1988). Conserved quaternary structure of ligand-gated ion channels: the postsynaptic glycine receptor is a pentamer. Proc. Natl. Acad. Sci. U.S.A. 85, 7394-7398. doi: 10.1073/pnas.85.19.7394

Laube, B., Maksay, G., Schemm, R., and Betz, H. (2002). Modulation of glycine receptor function: a novel approach for therapeutic intervention at inhibitory synapses? Trends Pharmacol. Sci. 23, 519-527. doi: 10.1016/S01656147(02)02138-7

Lee, B. H., Pyo, M. K., Lee, J. H., Choi, S. H., Shin, T. J., Lee, S. M., et al. (2008). Differential regulations of quercetin and its glycosides on ligand-gated ion channels. Biol. Pharm. Bull. 31, 611-617. doi: 10.1248/bpb.31.611

Lozovaya, N., Mukhtarov, M., Tsintsadze, T., Ledent, C., Burnashev, N., and Bregestovski, P. (2011). Frequency-dependent cannabinoid receptorindependent modulation of glycine receptors by endocannabinoid 2-AG. Front. Mol. Neurosci. 4:13. doi: 10.3389/fnmol.2011.00013

Lu, J.-M., Yan, S., Jamaluddin, S., Weakley, S. M., Liang, Z., Siwak, E. B., et al. (2012). Ginkgolic acid inhibits HIV protease activity and HIV infection in vitro. Med. Sci. Monit. 18, 293-298. doi: 10.12659/MSM.883261

Lynagh, T., and Pless, S. A. (2014). Principles of agonist recognition in Cys-loop receptors. Front. Physiol. 5:160. doi: 10.3389/fphys.2014.00160

Lynch, J. W. (2004). Molecular structure and function of the glycine receptor chloride channel. Physiol. Rev. 84, 1051-1095. doi: 10.1152/physrev.00042. 2003

Lynch, J. W. (2009). Native glycine receptor subtypes and their physiological roles. Neuropharmacology 56, 303-309. doi: 10.1016/j.neuropharm.2008.07.034

Lynch, J. W., Jacques, P., Pierce, K. D., and Schofield, P. R. (1998). Zinc potentiation of the glycine receptor chloride channel is mediated by allosteric pathways. J. Neurochem. 71, 2159-2168. doi: 10.1046/j.1471-4159.1998.71052159.x

Ma, J., Duan, W., Han, S., Lei, J., Xu, Q., Chen, X., et al. (2015). Ginkgolic acid suppresses the development of pancreatic cancer by inhibiting pathways driving lipogenesis. Oncotarget 6, 20993-21003. doi: 10.18632/oncotarget.3663

Maksay, G., Laube, B., Schemm, R., Grudzinska, J., Drwal, M., and Betz, H. (2009). Different binding modes of tropeines mediating inhibition and potentiation of alpha1 glycine receptors. J. Neurochem. 109, 1725-1732. doi: 10.1111/j.14714159.2009.06083.x

Malosio, M., Marqueze-Pouey, B., Kuhse, J., and Betz, H. (1991). Widespread expression of glycine receptor subunit mRNAs in the adult and developing rat brain. EMBO J. 10, 2401-2409.

Mascia, M. P., Mihic, S. J., Valenzuela, C. F., Schofield, P. R., and Harris, R. A. (1996). A single amino acid determines differences in ethanol actions on strychnine-sensitive glycine receptors. Mol. Pharmacol. 50, 402-406.

Meiselbach, H., Vogel, N., Langlhofer, G., Stangl, S., Schleyer, B., Bahnassawy, L., et al. (2014). Single expressed glycine receptor domains reconstitute functional 
ion channels without subunit-specific desensitization behavior. J. Biol. Chem. 289, 29135-29147. doi: 10.1074/jbc.M114.559138

Mihic, S. J., Ye, Q., Wick, M. J., Koltchine, V. V., Krasowski, M. D., Finn, S. E., et al. (1997). Sites of alcohol and volatile anaesthetic action on GABA(A) and glycine receptors. Nature 389, 385-389. doi: 10.1038/38738

Mukhtarov, M., Liguori, L., Waseem, T., Rocca, F., Buldakova, S., Arosio, D., et al. (2013). Calibration and functional analysis of three genetically encoded Cl(-)/pH sensors. Front. Mol. Neurosci. 6:9. doi: 10.3389/fnmol.2013.00009

Nassiri-Asl, M., Hajiali, F., Taghiloo, M., Abbasi, E., Mohseni, F., and Yousefi, F. (2014). Comparison between the effects of quercetin on seizure threshold in acute and chronic seizure models. Toxicol. Ind. Health 1, 9. doi: $10.1177 / 0748233713518603$

Nikolic, Z., Laube, B., Weber, R. G., Lichter, P., Kioschis, P., Poustka, A., et al. (1998). The human glycine receptor subunit $\alpha 3$ Glra3 gene structure, chromosomal localization, and functional characterization of alternative transcripts. J. Biol. Chem. 273, 19708-19714. doi: 10.1074/jbc.273.31.19708

Oertel, J., Villmann, C., Kettenmann, H., Kirchhoff, F., and Becker, C.-M. (2007). A novel glycine receptor beta subunit splice variant predicts an unorthodox transmembrane topology. Assembly into heteromeric receptor complexes. J. Biol. Chem. 282, 2798-2807. doi: 10.1074/jbc.M608941200

Olsen, R. W., and Sieghart, W. (2008). International Union of Pharmacology. LXX. Subtypes of $\gamma$-aminobutyric acidA receptors: classification on the basis of subunit composition, pharmacology, and function. Update. Pharmacol. Rev. 60, 243-260. doi: 10.1124/pr.108.00505

Oz, M. (2006). Receptor-independent actions of cannabinoids on cell membranes: focus on endocannabinoids. Pharmacol. Ther. 111, 114-144. doi: 10.1016/j.pharmthera.2005.09.009

Pistis, M., Belelli, D., Peters, J. A., and Lambert, J. J. (1997). The interaction of general anaesthetics with recombinant GABAA and glycine receptors expressed in Xenopus laevis oocytes: a comparative study. Br. J. Pharmacol. 122, 1707-1719. doi: 10.1038/sj.bjp.0701563

Pribilla, I., Takagi, T., Langosch, D., Bormann, J., and Betz, H. (1992). The atypical M2 segment of the b subunit confers picrotoxinin resistance to inhibitory glycine receptor channels. EMBO J. 11, 4305-4311.

Raafat, K., Breitinger, U., Mahran, L., Ayoub, N., and Breitinger, H. G. (2010). Synergisticinhibition of glycinergictransmissionin vitro and in vivo by flavonoids and strychnine. Toxicol. Sci. 118, 171-182. doi: 10.1093/toxsci/kfq245

Sato, K., Kiyama, H., and Tohyma, M. (1992). Regional distribution of cells expressing glycine receptor $\alpha 2$ subunit mRNA in the rat brain. Brain Res. 590 , 95-108. doi: 10.1016/0006-8993(92)91085-S

Satyan, K. S., Jaiswal, A. K., Ghosal, S., and Bhattacharya, S. K. (1998). Anxiolytic activity of ginkgolic acid conjugates from Indian Ginkgo biloba. Psychopharmacology 136, 148-152. doi: 10.1007/s002130050550

Singer, J. H., and Berger, A. J. (1999). Contribution of single-channel properties to the time course and amplitude variance of quantal glycine currents recorded in rat motoneurons. J. Neurophysiol. 81, 1608-1616.

Smart, T. G., and Paoletti, P. (2012). Synaptic neurotransmitter-gated receptors. Cold Spring Harb. Perspect. Biol. 4, a009662. doi: 10.1101/cshperspect.a009662

Takahashi, T., Momiyama, A., Hirai, K., Hishinuma, F., and Akagi, H. (1992). Functional correlation of fetal and adult forms of glycine receptors with developmental changes in inhibitory synaptic receptor channels. Neuron 9, 1155-1161. doi: 10.1016/0896-6273(92)90073-M

Taylor, P. M., Thomas, P., Gorrie, G. H., Connolly, C. N., Smart, T. G., and Moss, S. J. (1999). Identification of amino acid residues within GABA(A) receptor $\beta$ subunits that mediate both homomeric and heteromeric receptor expression. J. Neurosci. 19, 6360-6371.

Ude, C., Schubert-Zsilavecz, M., and Wurglics, M. (2013). Ginkgo biloba extracts: a review of the pharmacokinetics of the active ingredients. Clin. Pharmacokinet. 52, 727-749. doi: 10.1007/s40262-013-0074-5

Villmann, C., Oertel, J., Ma-Högemeier, Z.-L., Hollmann, M., Sprengel, R., Becker, K., et al. (2009). Functional complementation of Glral(spd-ot), a glycine receptor subunit mutant, by independently expressed C-terminal domains. J. Neurosci. 29, 2440-2452. doi: 10.1523/JNEUROSCI.440008.2009

Wang, Q., and Lynch, J. W. (2011). Activation and desensitization induce distinct conformational changes at the extracellular-transmembrane domain interface of the glycine receptor. J. Biol. Chem. 286, 38814-38824. doi: 10.1074/jbc.M111.273631

Waseem, T., Mukhtarov, M., Buldakova, S., Medina, I., and Bregestovski, P. (2010). Genetically encoded Cl-Sensor as a tool for monitoring of Cl-dependent processes in small neuronal compartments. J. Neurosci. Methods 193, 14-23. doi: 10.1016/j.jneumeth.2010.08.002

Webb, T. I., and Lynch, J. W. (2007). Molecular pharmacology of the glycine receptor chloride channel. Curr. Pharm. Des. 13, 2350-2367. doi: $10.2174 / 138161207781368693$

Xiong, W., Cheng, K., Cui, T., Godlewski, G., Rice, K. C., Xu, Y., et al. (2011). Cannabinoid potentiation of glycine receptors contributes to cannabis-induced analgesia. Nat. Chem. Biol. 7, 296-303. doi: 10.1038/nchembio.552

Xiong, W., Wu, X., Li, F., Cheng, K., Rice, K. C., Lovinger, D. M., et al. (2012). A common molecular basis for exogenous and endogenous cannabinoid potentiation of glycine receptors. J. Neurosci. 32, 5200-5208. doi: 10.1523/JNEUROSCI.6347-11.2012

Yang, Z., Aubrey, K. R., Alroy, I., Harvey, R. J., Vandenberg, R. J., and Lynch, J. W. (2008). Subunit-specific modulation of glycine receptors by cannabinoids and N-arachidonyl-glycine. Biochem. Pharmacol. 76, 1014-1023. doi: 10.1016/j.bcp.2008.07.037

Yang, Z., Taran, E., Webb, T. I., and Lynch, J. W. (2012). Stoichiometry and subunit arrangement of $\alpha 1 \beta$ glycine receptors as determined by atomic force microscopy. Biochemistry 51, 5229-5231. doi: 10.1021/bi300063m

Yevenes, G. E., and Zeilhofer, H. U. (2011a). Molecular sites for the positive allosteric modulation of glycine receptors by endocannabinoids. PLOS ONE 6:e23886. doi: 10.1371/journal.pone.0023886

Yevenes, G. E., and Zeilhofer, H. U. (2011b). Allosteric modulation of glycine receptors. Br. J. Pharmacol. 164, 224-236. doi: 10.1111/j.14765381.2011.01471.x

Zeilhofer, H. U., Wildner, H., and Yevenes, G. E. (2012). Fast synaptic inhibition in spinal sensory processing and pain control. Physiol. Rev. 92, 193-235. doi: 10.1152/physrev.00043.2010

Conflict of Interest Statement: The authors declare that the research was conducted in the absence of any commercial or financial relationships that could be construed as a potential conflict of interest.

Copyright (c) 2015 Maleeva, Buldakova and Bregestovski. This is an open-access article distributed under the terms of the Creative Commons Attribution License (CC BY). The use, distribution or reproduction in other forums is permitted, provided the original author(s) or licensor are credited and that the original publication in this journal is cited, in accordance with accepted academic practice. No use, distribution or reproduction is permitted which does not comply with these terms. 